\title{
2017 Yılında Güncellenen Ortaokul Beşinci Sınıf Fen Bilimleri Ders Kitabının Öğretmen Görüşlerine Göre Değerlendirilmesi
}

\section{Hasan BAKIRCI*， Emine GÜLSEVEN**}

Öz: Bu araştırmanın amacı, 2017 yılında güncellenen ortaokul beşinci sınıf Fen Bilimleri ders kitabının öğretmen görüşlerine göre değerlendirmektir. Araştırmanın katılımcıları, Van il merkezinde farklı ortaokullarda görev yapan 11 Fen Bilimleri öğretmeninden $(3$ erkek ve 8 kadın) oluşmaktadır. $\mathrm{Bu}$ çalışmada, nitel araştırma yaklaşımı olan olgubilim deseni kullanılmıştır. Veriler, araştırmacılar tarafından geliştirilen yarı yapılandırılmış mülakat formu ile toplanmıştır. Araştırmada elde edilen veriler, betimsel analiz ve içerik analizi yapılarak çözümlenmiştir. Öğretmenler, beşinci sınıf Fen Bilimleri ders kitabının öğretim programıyla uyumlu, öğrenci seviyesine uygun ve günlük hayatla ilişkili olduğunu belirtmişlerdir. Ayrıca kitabın; görsellik, ilgi çekicilik ve merak uyandırıcılık gibi ögeleri bakımından yeterli olduğunu dile getirmişlerdir. Öğretmenler, FeTeMM etkinlik sayısının az olması ve etkinliklerin öğrencilerin bilimsel süreç becerilerini ölçmede yetersiz olmasını kitabın sınırlılıkları olarak açıklamışlardır. Ders kitabının diğer bir sınırlılığı, öğrencilerin konuyu öğrenip öğrenmediğine dair yeterli sayıda değerlendirme sorularının olmamasıdır. Öğretmenler, etkinlikler için ders saatinin ve öğrencilerin değerlendirildiği soruların arttırılmasını, kitaptaki tüm etkinliklerin yapılmasını ve günümüz sınav sistemlerinin daha çok öğrencilerin bilimsel süreç becerilerine odaklandığı için ders kitaplarında bu tür etkinliklerin artırılmasını önermişlerdir.

Anahtar Kelimeler: Fen bilimleri öğretmeni, Ders kitabı inceleme, Öğretmen görüşleri.

\footnotetext{
*Dr. Öğr. Üyesi, Van Yüzüncü Yıl Üniversitesi, Eğitim Fakültesi, Email:hasanbakirci09@gmail.com Orcid No: 0000-00027142-5271.

${ }^{* * *}$ Yüksek Lisans Öğrencisi, Van Yüzüncü Y11 Üniversitesi, Eğitim Bilimler Enstitüsü, Email: minelvan65@gmail.com, Orcid No: 0000-0003-0946-2626.
}

\begin{tabular}{lll}
\hline Gönderim: 10.04.2018 & Kabul:15.07.2018 & Yayın:10.09.2018 \\
\hline
\end{tabular}




\section{Evaluation of Revised $5^{\text {th }}$ Grade Science Textbooks Based on the Teachers' Views in}

\section{7}

Abstract: The aim of this research is to evaluate according to the teachers' views of the $5^{\text {th }}$ grade science textbook revised in 2017. The research draws on views of teachers and the participants are 11 science teachers (8 female and 3 male teachers) working in different secondary schools in Van. The study employs qualitative approach and phenomenology design. Semi-structured interview protocol was used. Descriptive and content analysis were utilized for data analysis. Teachers stated that the $5^{\text {th }}$ grade science textbook is compatible with the curriculum, appropriate to the student level and related to daily life. They also stated that the book is sufficient in terms of providing rich visuals, fostering interest and arising curiosity. Teachers have described the limitations of the book as the limited number of STEM activities and inadequate activities to measure the scientific process skills of the students. Another limitation of the textbook is that there are not enough evaluation questions about whether the students have learned the subject. Teachers suggested that number of courses to accommodate the activities and the number of questions assessing students should be increased. They also highlighted that carrying out the activities is rather important for improving science skills of students as students generally focus on centralized exams.

Keywords: Science teacher, Evaluation of course book, Teacher views.

\section{Giriş}

Geçmişten günümüze kadar en yaygın biçimde kullanılan eğitim kaynaklarından biri yazılı materyallerdir. Yazılı materyallerin bireylere sağladığı en önemli avantaj, bilgiyi zaman ve mekan kısıtlaması olmaksızın ulaşılabilir kılmasıdır (Kılıç, 2005). Bu materyaller arasında belki de en önemlisi, öğretmen ve öğrenciler tarafından ortak kullanılabilen ders kitaplarıdır. Milli Eğitim Bakanlığı ders kitaplarını; "Her tür ve derecedeki örgün ve yaygın eğitim kurumlarında kullanılacak olan, konuları öğretim programları doğrultusunda hazırlanmış, 
ögrenim amacı ile kullanılan basılı eser" olarak tanımlamaktadır (Millî Eğitim Bakanlığı [MEB], 1995). Ders kitaplarını diğer kitaplardan ayıran en belirgin özellikleri ise; öğrenci seviyesine uygun olması, bilgileri bir bütün halinde sunması ve içerik bakımından konuların öğretim programı ile sınırlandırılmış olmasıdır (Keleş, 2001).

Ders kitapları, geçmişte olduğu gibi günümüzde de öğretme ve öğrenme sürecinin birincil kaynağı ve temel aracı olmuştur (Kolaç, 2009). Ayrıca öğrencilerin derse hazırlıklı gelme, konu tekrarı yapma, sınava çalışma gibi durumlarında çoğunlukla başvurdukları öğrenim sürecinin ayrılmaz parçasıdır (Tor ve Erden, 2004). Yapılan araştırmalarda, içeriği meydana getiren bilgilerin sistemli bir şekilde sunulduğu, ekonomik ve kolay ulaşılabilir olması, ünitelerin öğrenci seviyesi göz önünde bulundurularak hazırlanması gibi gerekçelerden dolayı ders kitapları sınıfta yazı tahtasından sonra en çok kullanılan öğretim aracı olduğu tespit edilmiştir (Karadaş, Yaşar ve Kırbaşlar, 2012).

Bilimsel bilginin arttığı, teknolojik gelişmelerin hızla ilerlediği ve hayatımızın her alanında etkilerinin görüldüğü çağımızda, insanların geleceği açısından fen eğitiminin önemli bir rol oynadığı açıkça görülmektedir (Aydoğdu ve Kesercioğlu, 2005). Fen Bilimleri, toplum ve çevrenin kalkınmasında temel olarak kabul edilmektedir. Ayrıca kişilere doğayı bilimsel yönden ele alıp onu inceleme firsatı vermektedir (Ünsal ve Güneş, 2003). Fen Bilimleri dersi ise öğrenciyi araştırmaya, sorgulamaya, bilgiyi zihninde yeniden yapılandırmaya olanak vererek bireysel öğrenmeye katkı sunmaktadır. Öğretmene ise öğretme ve öğrenme sürecinde rehberlik ve yönlendirme rolü vermektedir (Milli Eğitim Bakanlığı [MEB], 2013). Her geçen gün nitelikli insan gücüne olan ihtiyacın arttığı Türkiye'de 6 ile 14 yaş grubu çocukların devam ettiği zorunlu eğitim dönemini kapsayan ilkokul ve ortaokul kurumlarında fen bilimleri dersinin önemli bir yeri bulunmaktadır (Kaptan, 1999). Bundan dolayı Milli Eğitim Bakanlığı hızla değişen günümüz koşullarına adapte olmak adına 2005, 2013 ve 2017 yıllarında Fen Bilimleri Dersi Öğretim Programı’nda güncelleme yapmıştır. Ancak 2017 taslak Fen Bilimleri Dersi 
Öğretim Programı şimdiye kadar uygulanan öğretim programlarının hazırlanma ve yayımlanma safhalarından bir takım farklılıklar içermektedir. Nitekim 2017 Fen Bilimleri Dersi Öğretim Programı yayımlanmadan önce taslak öğretim programı "http://mufredat.meb.gov.tr" sitesinde yayımlanarak bir aylığına kamuoyunun ve paydaşların görüş ve önerilerine sunulmuştur. Kamuoyundan ve paydaşlardan gelen veriler 1şı̆̆ında, 2017 Fen Bilimleri Dersi Öğretim Programına son hali verilmiştir. Eğitim sisteminin temel belirleyicisi, öğrenci başarısının bire bir ilişkili olduğu öğretim programlarındaki bu değişiklikler çok önemlidir. Hatta çağın gereksinimleri doğrultusunda güncellenen öğretim programları nitelikli bireylerin yetiştirilmesine katkılar sağlamaktadır (Özcan ve Düzgünoğlu, 2017).

Çağın gereksinimleri doğrultusunda ve günlük hayatla ilişkili ortaokul fen programı, çocukların etkili fen öğrenmelerine yardım ederek kendi deneyimlerini yaşamalarını sağlar. Hazır bilgiyi aktaran program yerine, bilgiye ulaşma yollarını gösteren, problem çözme becerilerini geliştiren, çok konu işlemek yerine birkaç konuyu daha derinden işleyen bir fen programının daha etkili olduğunu gösteren birçok çalışma vardır. Bugünkü fen eğitiminde yaygın olan tema “Az daha çoktur" sözleriyle ifade edilmektedir (Kaptan, 1999). Fen Bilimleri dersinin temel amacı, öğrencilerde merak uyandırmak, onları araştırmaya sevk etmek, yaratıcılıklarını ön plana çıkarmaktır. Bu amaç duğrultusunda fen öğretim programları 2005 yılında yapılandırmacı yaklaşım olarak, 2013 yılında araştırma-sorgulamaya dayalı öğretim yaklaşımı olarak geliştirilerek uygulanmıştır (MEB, 2013). Bu şekilde öğrencinin kalıplaşmış bilgileri ezberlemeleri yerine; araştırarak, sorgulayarak, keşfederek, hipotezler kurarak ve bunları yorumlayarak çözüme ulaşmasını ve öğrendiklerini yapılandırarak gerçekleştirmesi sağlanmıştır (Karamustafaoğlu, Salar ve Celep, 2015). Fen Bilimleri Dersi Öğretim Programı, fen eğitimi alanında uzun zamandır desteklenen yapılandırmacı yaklaşımı yeniden biçimlendirmekte ve 21. yüzyıl becerileri olan eleştirel düşünme, problem çözme, yaratıcı düşünme gibi bilimsel süreç becerilerini disiplinler arası bir anlayışla düzenleyerek 
öğrencilerin araştırmaya dayalı öğrenme ortamlarını zenginleştirmiştir (Kardaş, Anagün ve Yalçınoğlu, 2014).

Bir ders kitabı öğretim programının ögeleriyle paralellik taşımalıdır. Uygun zihinsel süreçlere ve öğrenme ilkelerine göre düzenlenmelidir. Somuttan soyuta, basitten karmaşığa, bilinenden bilinmeyene doğru sıralanmalıdır. Öğrencilerin gelişim özelliklerini göz önünde bulundurarak ölçülebilir ve gözlemlenebilir davranışları içermelidir. İçerik ünite konularını kapsamalı ve konular birbiriyle bağlantılı olarak sunulmalıdır. Öğrencileri seviyelerine uygun düşünmeye, araştırmaya, deney yapmaya ve yaratıcılığa sevk edecek sorular sorarak onlarda eleştirel düşünme, problem çözme gibi becerileri geliştirmelidir. Ders kitaplarında sunulan bilgiler doğru ve bilimsel olmalıdır. Bilgiler konu alanının amacına, yöntemine, işleyişine ve konu alanının terimlerine uygun olmalı. Örneklemeler güncel, etkinlikler uygulanabilir ve görseller öğrencinin ilgisini çekecek şekilde sunulmalıdır (URL-1, 2017).

Eğitim sisteminde çok önemli bir yere sahip olan ders kitapları ile ilgili yapılan çalışmalar, eğitim sistemimizin gelişmesine katkı sağlamaktadır. Bu konudaki çalışmalar incelendiğinde, ders kitabını destekleyici test ve alıştırma kitaplarının olmayışı, yardımcı araç gerecin bulunmaması öğretmenlerce büyük bir eksiklik olarak görülmüştür (Yıldırım ve Ateş, 2002). Dördüncü sınıf ders kitaplarındaki etkinliklerin kısmen, beşinci sınıf ders kitaplarında ise etkinliklerin çoğunun ilgili kazanımlarla ilgili olduğu belirtilmiştir. Fakat birkaç tane etkinliğin kazanımlardan bağımsız olduğu, bazı kazanımlara yönelik ise birden fazla etkinlik bulunduğu, bazı kazanımlara ait etkinliklerin ise bulunmadığı belirlenmiştir. Etkinlik sonrası verilen ifadelerle ilgili bulgular incelendiğinde eksik ve yanlış tanımlara rastlanmıştır (Karadaş ve ark. 2012). Yapılan analizler sonucunda incelenen ders kitaplarında, metinlerle yapılan bilgi sunumlarının dışında, çoğunlukla fotoğraf ve resim gösterim türlerinden yararlanıldığı, buna bağlı olarak da kullanılan gösterim türleri arasındaki ilişkilendirmelerde geçişlerin yetersiz olduğu görülmüştür (Kurnaz, Çevik ve Bayri, 2016). 
Öğretmenler, ders kitabında bazı yetersizlikler olduğunu ve düzenlemeler yapılması gerektiğini belirtmişlerdir. Bunun yanında kitabın içerik kısmının ve ölçme değerlendirme bölümlerinin yetersiz olduğunu, öğretmen kılavuz ve öğrenci çalışma kitabının olmamasını büyük bir eksiklik olduğunu dile getirmişlerdir (Karamustafaoğlu ve ark. 2015). Fen Bilimleri ders kitabındaki fizik konularının yer aldığı üniteler incelendiğinde; içerik, eğitsel tasarım ve görsel sunum bakımlarından, sıkıntıların olduğu görülmüştür. Özellikle, “Elektrik” ünitesinde yer alan hatalar, öğrencilerde kalıcı ve yanlış kavramaların zemin bulmasına neden olmaktadır (Ünsal ve Güneş, 2003). Yapılan analizde, ortaokul beşinci sınıf ders kitabında yer alan “Maddenin Değişimi ve Tanınması” ünitesinin eleştirel düşünme basamaklarından açıklık basamağını karşılamadığı, doğruluk, yeterlilik ve kesinlik basamaklarını kısmen karşıladığı, ilişiklik ve derinlik basamaklarını karşıladığı sonucuna ulaşılmıştır (Aybek, Çetin ve Başarır, 2014). Kitaptaki konuların, öğrencilerin yakın çevresi, bireysel ihtiyaçları ve günlük yaşantısı ile ilgili soruları kapsıyor olması önemli görülmüştür. Ayrıca, deneyler için seçilen malzemelerin, araç-gereçlerin kolay elde edilebilir nitelikte olduğu anlaşılmıştır. Fakat; kitabın içinde farklı yazı karakterlerinin kullanılması, öğrencilerin okurken kısmen de olsa zorlanmalarına neden olmaktadır. Ayrıca; ders kitabında bulunan bazı ifadelerdeki gölgelendirmelerin öğrencilerin okurken yanılmalarına ve bazı ana başlıkların kitabın katlanan kısmında yazıldığı için rahat okunamamasına sebep olmaktadır (Maskan, Maskan ve Atabay, 2007).

Öğrencilerin öğrenme hedeflerine, yaparak yaşayarak ulaşmasının öğretim programları aracılığıyla sağlandığı düşünüldüğünde, bireylerin hatta nesillerin her geçen gün değişen dünyaya uyum sağlayabilmesi adına yapılan güncel olma hamlelerinden birisi de öğretim programlarında meydana gelen değişikliklerdir (Drake, Land ve Tyminski, 2014; Taber ve Akpan, 2017, s. 23). Türkiye'de belirli dönemlerde yukarıda bahsedilen gerekçeler doğrultusunda öğretim programlarında değişikliğe gidilmiştir. Ders kitaplarının öğretim 
programları temel alınarak hazırlanmaktadır. Ders kitaplarının öğretimdeki yeri, öğretim programının belirttiği eğitim öğretim ilkelerine göre düzenlenmektedir. 2017 yılında Fen Bilimleri Dersi Öğretim Programı güncellenerek uygulanmaya konulmuş ve ortaokul beşinci sınıftan itibaren kademeli olarak uygulanması kararlaştııılmıştır. Programda güncellenmeye gidilmesi ile birlikte ders kitaplarının da güncellenme ihtiyacı ortaya çıkmıştır. Güncellenen ders kitaplarından birisi de ortaokul beşinci sınıf Fen Bilimleri ders kitabı olmuştur.

Güncellenen Fen Bilimleri ders kitabı 2017-2018 eğitim öğretim yılından itibaren beşinci sınıflarda uygulanmaya başlanmıştır. Ders kitaplarını takip ederek derslerini yürüten öğretmenlerin bu konudaki görüşlerinin önemli olduğu düşünülmektedir. Alan yazında bu konuda çalışmaya rastlanmamış olması bu çalışmayı önemli kılmaktadır. Yukarıda sunulan literatürden hareketle, ders kitaplarının incelenmesini konu alan çalışmalarda farklı bakış açılarının temel alındığı ancak, ders kitaplarının öğretim programına uygunluğu ile ilgili yeterli çalışmanın yer almadığı tespit edilmiştir. Bu nedenle ortaokul beşinci sınıf Fen Bilimleri ders kitabının programa uygunluğu, bilimsel içeriği, görsel düzeni, güncel olması, gibi temalarda öğretmen görüşüne başvurulmuştur. Dolaysıyla bu araştırmanın amacı, 2017 Fen Bilimleri Dersi Öğretim Programına göre hazırlanmış ortaokul beşinci sınıf Fen Bilimleri ders kitabına ilişkin öğretmen görüşlerini tespit etmektir. Bu amaç doğrultusunda aşağıdaki alt problemlere cevap aranmıştır:

2017 yılında güncellenen beşinci sınıf Fen Bilimleri ders kitabında yeniliklerin neler olduğu ve bu yeniliklerin öğrencilerin öğrenmelerini nasıl etkileyeceğini düşünüyorsunuz?

Güncellen Fen Bilimleri ders kitabının öğretim programına uygunluğu konusundaki düşünceleriniz nelerdir?

Güncellenen Fen Bilimleri ders kitabını bilimsel içerik, görsel düzen ve etkinlikler açısından nasıl buluyorsunuz? 


\section{Yöntem}

\section{Araştırmanın Deseni}

$\mathrm{Bu}$ araştırma, 2017 yılında yenilenen ortaokul beşinci sınıf Fen Bilimleri ders kitabına yönelik öğretmen görüşlerini araştıran nitel bir çalışmadır. Çalışma, nitel araştırma yaklaşım desenlerinden olgubilim desenine göre tasarlanmıştır. Bu desende, farkında olunan ancak ayrıntılı ve derinlemesine bir görüşe sahip olunmayan olgular üzerine odaklanılmaktadır (Yıldırım ve Şimşek, 2011). Ayrıca bu desen, günlük deneyimlerimizin anlamı ve doğası hakkında derinlemesine bir anlayışın kazanılmasını sağlamaktadır (Patton, 2014). Bu araştırmada, yenilenen ortaokul beşinci sınıf Fen Bilimleri dersi olgusuna ilişskin Fen Bilimleri öğretmenlerinin görüşleri ve deneyimleri irdelendiği için, olgubilim deseni kullanılmıştır.

\section{Katılımcilar}

Bu araştırma, 2017-2018 eğitim-öğretim yılında, Van İl Milli Eğitim Müdürlüğü’ne bağlı farklı ortaokullarında görev yapan beşinci sınıf Fen Bilimleri ders kitabını kullanan 8’i kadın 3’ü erkek olmak üzere 11 Fen Bilimleri öğretmeni ile yürütülmüştür. Çalışmaya katılan öğretmenlerin yaşları 26-35 ve mesleki deneyimleri ise 3-9 yıl aralığındadır. Katılımcılar seçiminde ölçüt örneklem yöntemi kullanılmıştır. Bu örneklem seçimi; konu ile ilgili tecrübeye sahip, ders kitabını kullanmış ya da kullanıyor durumda olan öğretmenler arasından yapılmaktadır (Yıldırım ve Şimşek, 2011). Öğretmenlere özellikle araştırmanın amacı ve içeriği hakkında bilgi verildikten sonra gönüllü olarak katılan 11 Fen Bilimleri öğretmeni çalışmaya dahil edilmiştir. Çalışmaya katılan öğretmenler $\mathrm{K}_{1}, \mathrm{~K}_{2}, \mathrm{~K}_{3}, \mathrm{~K}_{4}, \ldots \mathrm{K}_{11}$ şeklinde kodlanarak demografik özellikleri Tablo-1'de verilmiştir. 
Tablo 1. Çalışma Grubuna Ait Demografik Bilgiler

\begin{tabular}{|c|c|c|c|}
\hline & Cinsiyet & Yaş & Mesleki Deneyim \\
\hline $\mathbf{K}_{\mathbf{1}}$ & Kadın & 26 & 3 y1l \\
\hline $\mathbf{K}_{\mathbf{2}}$ & Kadın & 27 & 3 y1l \\
\hline $\mathbf{K}_{\mathbf{3}}$ & Kadın & 28 & 3 y1l \\
\hline $\mathbf{K}_{\mathbf{4}}$ & Erkek & 30 & 4 y1l \\
\hline $\mathbf{K}_{\mathbf{5}}$ & Kadın & 29 & 4 y1l \\
\hline $\mathbf{K}_{\mathbf{6}}$ & Erkek & 27 & 4 y1l \\
\hline $\mathbf{K}_{\mathbf{7}}$ & Kadın & 27 & 5 y1l \\
\hline $\mathbf{K}_{\mathbf{8}}$ & Kadın & 30 & 6 y1l \\
\hline $\mathbf{K}_{\mathbf{9}}$ & Kadın & 29 & 6 y1l \\
\hline $\mathbf{K}_{\mathbf{1 0}}$ & Kadın & 31 & 8 y1l \\
\hline $\mathbf{K}_{\mathbf{1 1}}$ & Erkek & 35 & 9 y1l \\
\hline
\end{tabular}

\section{Veri Toplama Aracı}

Bu çalışmada, öğretmenlerin Fen Bilimleri ders kitabı hakkında düşüncelerinin ortaya çıkarılması amaçlandığı için nitel veri toplama tekniklerinden yarı yapılandırılmış mülakat kullanılmıştır. Bu araştırma tekniği, seçilmiş bir konuda derinlemesine sorular sorarken, cevap eksik veya anlaşılır değilse tekrar soru sorarak durumu anlaşılır hale getirip cevapları tamamlama firsatı vermesi yönünden avantajlıdır (Çepni, 2007). Hazırlanan yarı yapılandırılmış mülakat soruları uzman görüşleri dikkate alınarak incelenmiş Miles ve Huberman'ın (1994) önerdiği güvenilirlik hesaplaması (Güvenirlik=Görüş birliği/Görüş Ayrılığ 1 + Görüş birliği x 100) kullanılarak veriler elde edilmiştir. Böylece araştırmanın amacına bağlı kalınarak uygun olmayan sorular yeniden düzenlenmiş ya da çıkartılmıştır. Hazırlanan soruların öğretmenlerin ders kitabını değerlendirmeye rehberlik edebilecek şekilde olmasına dikkat edilmiştir. Katılımcılarla yüz yüze gerçekleştirilen mülakatlar, ses kayıt cihazıyla, katılımcıların onayı alınarak kaydedilmiştir. Mülakatlardan sonra kaydedilen veriler, metne dönüştürüldükten sonra katılımcılara verilerek, kayıtların yanlışsız ve eksiksiz olduğunun doğrulanması sağlanmış ve verilerin uyum oranının $\% 78$ olduğu tespit edilmiştir. $\mathrm{Bu}$ yolla verilerin güvenirliği artırılmıştır. 


\section{Verilerin Analizi}

Çalışmanın veri analizinde betimsel analiz ve içerik analizi tekniğinden yararlanılmıştır. Betimsel analiz, farklı veri toplama teknikleri ile elde edilmiş verilerin daha önceden belirlenmiş başlıklar yani temalar altında özetlenerek yorumlanmasıdır. Elde edilen veriler araştırma sorularına göre sınıflandırılabileceği gibi, verileri toplama sırasında elde edilen bilgiler doğrultusunda da düzenlenebilir (Yıldırım ve Şimşek, 2011). Araştırmacı mülakatları tamamladıktan sonra kayıtların analiz aşamasına geçmiştir. Bu aşamada ise verilerin içeriğinde yer alan kavramları ve bu kavramlar arasındaki ilişkileri ortaya çıkarmak için içerik analizi yöntemi kullanılmıştır (Miles ve Huberman, 1994; Yıldırım ve Şimsek, 2011). Kayıtların analizinde her bir öğretmen için ayrı bir mülakat formu kullanılmıştır. Mülakat sırasında kullanılan ses kayıtlarının, her öğretmen için hiçbir değişiklik yapılmadan dökümü yapılmıştır. $\mathrm{Bu}$ dökümler alan uzmanı tarafından ses kayıtları ile karşılaştırılmış ve doğrululukları incelenmiştir. Öğretmenlerden alınan araştırma sorularına ilişkin bilgiler tablolara aktarılmıştır.

\section{Bulgular}

2017 yılında Fen Bilimleri Dersi Öğretim Programı’nda yapılan değişiklikler hakkında Fen Bilimleri öğretmenlerinin görüşleri Tablo 2'de verilmiştir.

Tablo 2. Fen Bilimleri Öğretmenlerinin "2017 yllında Fen Bilimleri Dersi Öğretim Programı'nda yapılan değişiklerin neler olduğunu ve bu konu hakkındaki düşünceleriniz nelerdir?" Sorusuna Vermiş Olduklarl Cevaplardan Oluşturulan Tema ve Kodlar

\begin{tabular}{|c|c|c|c|c|c|c|c|c|c|c|c|c|}
\hline \multirow[b]{2}{*}{ Tema } & \multirow[b]{2}{*}{ Kodlar } & \multicolumn{11}{|c|}{ Fen Bilimleri Öğretmenleri } \\
\hline & & $\mathbf{K}_{\mathbf{1}}$ & $\mathbf{K}_{2}$ & $\mathbf{K}_{3}$ & $\mathbf{K}_{4}$ & $\mathbf{K}_{5}$ & $\mathbf{K}_{6}$ & $\mathbf{K}_{7}$ & $\mathbf{K}_{8}$ & $K_{9}$ & $\mathbf{K}_{10}$ & $K_{11}$ \\
\hline \multirow{6}{*}{ 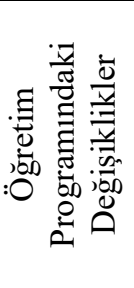 } & Ünite değişikliğinin olması & + & + & + & + & - & + & - & + & + & + & + \\
\hline & FeTeMM eğitiminin yer almas1 & + & + & - & + & - & - & + & + & - & + & + \\
\hline & Kitabın ilgi çekici hale gelmesi & + & + & - & - & + & - & + & - & + & + & + \\
\hline & $\begin{array}{l}\text { Uygulanabilir etkinliklerin yer } \\
\text { alması }\end{array}$ & + & + & + & - & - & - & + & - & - & + & + \\
\hline & Konuların sadeleştirilmiş olması & - & - & + & - & + & + & + & + & + & - & - \\
\hline & Kazanım sayısının azaltılması & - & - & - & + & + & - & + & + & + & - & + \\
\hline
\end{tabular}

Tablo 2 incelendiğinde; öğretmenler öğretim programında yapılan değişiklikleri, ünite değişikliğinin yapılması, FeTeMM eğitiminin yer alması, konuların ilgi çekici hale gelmesi, uygulanabilir etkinliklerin yer alması ve sadelik şeklinde açıklama yapmışlardır. Öğretmenlerin 
9'u öğretim programında; ünite değişikliğinin yapıldığını belirtmişlerdir. $K_{2}$ nolu öğretmen; “Eski programda son ünitede yer alan uzay konusunun ilk üniteye alınması çok güzel olduğunu düşünüyorum. Çocukların tatil dönüşü okula uyum sağlamalarını kolaylaştırıyor ve ögrencilerin ilgisini çeken konulardan birisi de uzay konusudur.” şeklinde görüşünü beyan etmiştir. Öğretmenlerin 7'si öğretim programına FeTeMM eğitiminin eklendiğini ve kitabın ilgi çekici hale geldiğini belirtmişlerdir. $\mathrm{K}_{10}$ nolu katılımc1; "Ĕgitim öğretimin son ünitesinde FeTeMM etkinliklerinin verilmesi ögrencilere somut örnek olması ve meslek alanlarını göstermesi açısından önemli ve öğrencilerin derse olan ilgisini artırmıştır.” Öğretmenlerin 5'i kazanım sayısının azaltıldığını ve konuların sadeleştirildiğini dile getirmişlerdir. $\mathrm{K}_{8}$ nolu katılımc1; "Konuların yerleri değişmişstir. Konularda sadeleştirilmeye gidilmiştir. Kazanımlar azaltılmıştır, böylece çocukların daha az bilgiyi daha derin bir şekilde öğrenmeleri sağlanmıştır." şeklinde görüş bildirmiştir. $\mathrm{K}_{11}$ nolu katılımc1; “Konular sadeleş̧tirilmiş, kazanımlar azaltılmış ve ögrencinin yoğun bilgi kalabalığı arasında bocalaması engellenmiştir." şeklinde düşüncesini dile getirmiştir. Öğretmenlerin 6'si ise kitabın uygulanabilir etkinlikler içerdiğini açıklamışlardır. $\mathrm{K}_{2}$ nolu öğretmen; "Kitabın sonuna FeTeMM'in eklenmesi uygulanabilirliği artırmış. Çocuklarda yaparak yaşayarak öğrenmeyi ve kalıcı izli davranış değişikliğini sağlayacă̆ını düşünüyorum." şeklinde görüşünü belirtmiştir.

Beşinci sınıf Fen Bilimleri ders kitabının genel taslağı hakkındaki Fen Bilimleri öğretmenlerinin görüşleriniz Tablo 3'te verilmiştir. 
Tablo 3. Fen Bilimleri Öğretmenlerinin "Beşinci Sınıf Fen Bilimleri Ders kitabının genel taslağı hakkındaki görüşleriniz nedir?” Sorusuna Vermiş Oldukları Cevaplardan Oluşturulan Tema ve Kodlar

\begin{tabular}{|c|c|c|c|c|c|c|c|c|c|c|c|c|}
\hline \multirow[b]{2}{*}{ Tema } & \multirow[b]{2}{*}{ Kodlar } & \multicolumn{11}{|c|}{ Fen Bilimleri Öğretmenleri } \\
\hline & & $\mathbf{K}_{1}$ & $\mathbf{K}_{2}$ & $\mathbf{K}_{3}$ & $\mathbf{K}_{4}$ & $\mathbf{K}_{5}$ & $\mathrm{~K}_{6}$ & $\mathbf{K}_{7}$ & $\mathbf{K}_{8}$ & K9 & $\mathbf{K}_{10}$ & $\mathbf{K}_{11}$ \\
\hline \multirow{4}{*}{ 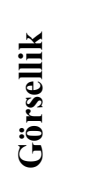 } & Parlak olması & + & + & + & + & + & + & + & + & - & - & - \\
\hline & Renkli olması & + & - & + & - & + & + & + & + & + & + & - \\
\hline & Canlı olması & - & + & - & - & + & - & + & - & - & + & - \\
\hline & Merak uyandırıcı olması & + & + & - & - & + & - & + & - & + & + & - \\
\hline \multirow{4}{*}{ 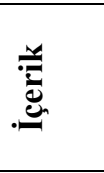 } & Konular & - & + & - & + & + & + & - & + & + & + & - \\
\hline & Etkinlikler & + & + & + & - & + & - & - & + & - & - & + \\
\hline & Ölçme ve değerlendirme & - & + & - & + & - & - & + & + & - & - & - \\
\hline & Sinırlılıklar & - & + & - & - & - & + & - & - & - & - & + \\
\hline
\end{tabular}

Öğretmenlerin ders kitabının genel taslağı hakkında görüşleri "Görsellik" ve "İçerik" teması altında toplanmıştır. Öğretmenlerin sekizi ders kitabının görselliği ile ilgili olarak, parlak, renkli, canlı ve merak uyandırıcı özelliklerini ön plana çıkarmışlardır. Bu konuda öğretmenlerden $\mathrm{K}_{7}$; “Kitap parlak ve çok renkli olmuş. Göze hitap ediyor. Resimlerdeki canlılık öğrencilerin kitaba ilgisini yani konulara merakını artıracaktır." şeklinde görüşünü ifade etmiştir. $\mathrm{K}_{10}$ nolu öğretmen ise; "Kitap canlı ve çok renkli olmuş bu da beşinci sınıf ögrencilerinde özellikle merak uyandırma ve ilgiyi toplama yönünden çok iyi olmuş diye düşünüyorum." şeklinde söylemiştir. Öğretmenler ders kitabının genel taslağının içerik teması altındaki görüşleri, konular, etkinlikler, ölçme ve değerlendirme ve sınırlılıklar şeklindedir. Bu konuda öğretmenlerden $\mathrm{K}_{2}$ nolu öğretmen; “Ders kitabını çok beğendim adeta bilim çocuk dergileri gibi olmuş. Gereksiz bilgilere yer verilmemiş yani konular sadeleştirilmiş, yurdun her tarafında yapılabilecek etkinlikler var bunlar çocukların etkin bir şekilde katılımını artıracaktır. Ünite sonlarında yer alan ölçme değerlendirme amaçlı geçmiş yılların sınav soruları da çocuklar için son derece yararlıdır. Fakat soru sayısı kısıtlı bu yüzden de çocukların konuları pekiştirmesi için yeterli değildir.” şeklinde görüşünü açıklamıştır. K $\mathrm{K}_{8}$ nolu öğretmen ise; “Geçmiş yıllarda ders kitabı öğrencilerin konu hakkında gereken bilgiyi alması yönünden yeterli değildi ve değerlendirme çalışmaları yönünden çok eksikti. Fakat yeni ders kitabı hem konu anlatımı olarak hem de ölçme değerlendirme çalışmaları ile etkinlik 
çalışmaları açısından daha iyi bir düzeyde hazırlanmışsır. Gereksiz bilgi kalabalığından arındırılmış olması kitabı daha eğlenceli bir duruma getirmiştir." şeklinde ifade etmiştir.

Fen Bilimleri öğretmenlerinin ders kitabındaki yeniliklerin neler olduğu ve bu yeniliklerin öğrencilerin öğrenmelerini nasıl etkileyecek konusundaki görüşleri Tablo 4'te verilmiştir.

Tablo 4. Fen Bilimleri Öğretmenlerinin "Fen Bilimleri ders kitabındaki yenilikler nelerdir? Bu yeniliklerin öğrencilerin öğrenmelerini nasıl etkileyeceğini düşünüyorsunuz?” Sorusuna Vermiş oldukları Cevaplardan Oluşturulan Tema ve Kodlar

\begin{tabular}{|c|c|c|c|c|c|c|c|c|c|c|c|c|}
\hline \multirow[b]{2}{*}{ Tema } & \multirow[b]{2}{*}{ Kodlar } & \multicolumn{11}{|c|}{ Fen Bilimleri Öğretmenleri } \\
\hline & & $\mathbf{K}_{1}$ & $\mathbf{K}_{2}$ & $\mathbf{K}_{3}$ & $\mathbf{K}_{4}$ & $\mathbf{K}_{\mathbf{5}}$ & $\mathbf{K}_{6}$ & $\mathbf{K}_{7}$ & $\mathbf{K}_{8}$ & $\mathbf{K}_{9}$ & $\mathbf{K}_{10}$ & $\mathbf{K}_{11}$ \\
\hline \multirow{6}{*}{ 离 } & Bilim kahramanları & + & + & + & + & + & - & + & + & + & + & + \\
\hline & Yaratıcı etkinlikler & + & + & - & + & - & - & + & + & - & + & + \\
\hline & Güncel örnekler & + & + & - & + & + & - & + & - & + & + & + \\
\hline & Göster kendini etkinlikler & + & + & + & - & - & - & + & - & - & + & + \\
\hline & Sinav merkezli sorular & - & - & + & - & + & + & + & + & + & - & - \\
\hline & Konuyu pekiştirici etkinler & - & - & - & + & + & - & + & + & + & - & + \\
\hline \multirow{7}{*}{ 总 } & Kalıcı öğrenmeyi sağlama & + & + & + & + & + & + & + & + & + & + & + \\
\hline & $\begin{array}{l}\text { Yeteneklerinin farkında olmalarını } \\
\text { sağlama }\end{array}$ & + & + & + & + & + & + & - & + & + & + & - \\
\hline & Öğrenmeyi kolaylaştırma & + & + & - & + & + & + & + & + & - & - & + \\
\hline & Bilim insanı olmayı özendirme & + & - & + & - & + & + & + & - & - & + & + \\
\hline & Yaratıcı düşünmeyi sağlama & - & + & + & + & - & + & - & + & - & + & + \\
\hline & 21. yüzyıl becerileri kazandırma & + & - & - & + & + & - & + & - & + & - & - \\
\hline & Akademik başarıyı sağlama & - & - & + & + & - & + & + & - & + & + & - \\
\hline
\end{tabular}

Tablo 4 incelendiğinde öğretmenler kitaptaki yenilikleri; bilim kahramanları, yaratıcı etkinlikler, güncel örnekler, göster kendini ve konu pekiştirici etkinlikler şeklinde açıklamışlardır. Öğretmenlerin tamamına yakını ders kitaplarında bilim kahramanlarının ve yaratıcı etkinliklerin yer almasını yenilik olarak belirtmişler. Bu konuda $\mathrm{K}_{2}$ rumuzlu öğretmen; “Kitapta özellikle dikkatimi çeken bilimin kahramanları bölümü olmuştur. Bu bölümü okuyan çocuk bilim adamlarının aslında kendileri gibi olduğu ve onlarında isterlerse bilim adamı olabileceklerini benimsetiyor. Örneğin; Türk bilim insanlarından Ali Kuşçu verilmiştir. Özellikle Türk bilim adamının verilmesi çocukları daha çok güdüleyeceğini düşünüyorum.” şeklinde görüşünü ifade etmiştir. Öğretmenlerden 6's1 göster kendini etkinliklerinin kitapta yer alması, öğrencilerin bireysel farklılıklarının ve yaratıcılıklarının farkında olmalarını sağlayacaklarını belirtmişlerdir. $\mathrm{Bu}$ konuda $\mathrm{K}_{6}$ nolu öğretmen; “Ders kitabında özellikle 
YYÜ Ĕ̌itim Fakültesi Dergisi (YYU Journal of Education Faculty), 2018; 15(1):638-671, http://efdergi.yyu.edu.tr

yaratıcıllğa önem veren göster kendini kısımları çok iyi düşünülmüş etkinliklerdir. Öğrencilerin ögrenmelerini kolaylaştıracă̆ını düşünüyorum. Mesela; Güneş, Dünya ve Ay ünitesindeki göster kendini bölümünde çocuktan kendini bir astronot gibi düşünmesini ve uzayda nelerle karşılaşabileceği soruluyor. Buda onu yaratıcı düşünmeye sevk ettirecektir. ” şeklinde görüşünü dile getirmiştir. Öğretmenler ders kitaptaki yeniliklerin; öğrenmeyi kolaylaştıracağını, kalıcı öğrenmeyi ve yeteneklerinin ortaya çıkmasını sağlayacağını, bilim insanı olmayı özendireceğini, yaratıcı düşünmeyi sağlayacağını ve akademik başarıyı artıracağını dile getirmişlerdir. Öğretmenlerden $\mathrm{K}_{4}$ "Ders kitabında yer alan etkinliklerin güncel ve sınavda çıkabilecek türden hazırlanmış olması öğrencilerde öğrenmeyi kolaylaştırarak akademik başarıyı artıracaktır.” şeklinde açıklama yapmıştır. Öğretmenlerin 4'ü güncel hayattan örneklerin verildiğini ve bu örneklerin öğrencilerde Fen Bilimlerinin dersinin günlük hayatla iç içe olduğunu anlayacaklarını belirtmişlerdir. Buna göre $\mathrm{K}_{8}$ nolu öğretmen; “Ders kitabındaki konular sadeleştirilmiş ve günlük hayattaki örnekler verilmiştir. Mesela; sürtünme kuvveti konusunda günlük hayatta karşılaştıkları örnekler verilmiş bunlar, arabaların lastiklerine zincir takılması, buz tutan yollara tuz dökülmesi, Istanbul'un fethinde kullanılan gemilerin altlarına tekerlek takılması gibi. Böylece çocuklar öğrendiklerini günlük yaşamda da kullanabileceklerini ögrreniyorlar. Bu yüzdende kitap güzel hazırlanmıştır” şeklinde görüşünü ifşa etmiştir.

Fen Bilimleri öğretmenlerinin, Fen Bilimleri ders kitabındaki etkinlikler hakkında görüşleri Tablo 5'de verilmiştir. 
Tablo 5. Fen Bilimleri Öğretmenlerinin "Fen Bilimleri ders kitabındaki etkinliklerin yeterliliği ve ögrenmeye olan katkısı hakkında düşünceleriniz nelerdir?” Sorusuna Vermiş Oldukları Cevaplardan Oluşturulan Tema ve Kodlar

\begin{tabular}{|c|c|c|c|c|c|c|c|c|c|c|c|c|}
\hline \multirow{4}{*}{ 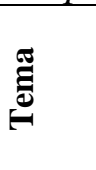 } & \multirow[t]{2}{*}{ Kodlar } & \multicolumn{11}{|c|}{ Fen Bilimleri Öğretmenleri } \\
\hline & & $\mathrm{K}_{1}$ & $\mathrm{~K}_{2}$ & $\mathrm{~K}_{3}$ & $\mathrm{~K}_{4}$ & $\mathrm{~K}_{5}$ & $\mathrm{~K}_{6}$ & $\mathrm{~K}_{7}$ & $\mathrm{~K}_{8}$ & $\mathrm{~K}_{9}$ & $\mathrm{~K}_{10}$ & $\mathrm{~K}_{11}$ \\
\hline & Yeterli buluyorum & + & + & + & - & + & + & + & - & + & - & - \\
\hline & Yetersiz buluyorum & - & - & - & + & - & - & - & + & - & + & + \\
\hline \multirow{6}{*}{ 离 } & Yaparak yaşayarak öğrenmeyi sağlama & + & + & + & - & + & + & + & - & + & - & - \\
\hline & Araştırmaya sevk etmesi & + & + & + & - & + & + & + & - & + & - & - \\
\hline & 21. yüzyıl becerilerini geliştirmesi & + & + & + & - & + & + & + & - & + & - & - \\
\hline & Günlük hayatla ilişkili olması & + & + & + & - & + & - & + & - & + & - & - \\
\hline & Bireysel farklılıkları dikkate alması & + & - & + & - & + & - & + & - & + & - & - \\
\hline & Düşünmeyi sağlaması & - & + & + & - & + & + & + & - & - & - & - \\
\hline \multirow{6}{*}{ 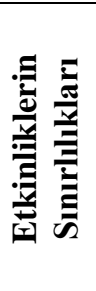 } & Etkinlik sayısının az olması & - & - & - & + & - & - & - & + & - & + & + \\
\hline & Ekonomik olmaması & - & - & - & + & - & - & - & + & - & + & + \\
\hline & Konuyla ilgi yeterli sorunun olmaması & - & - & - & + & - & - & - & + & - & + & + \\
\hline & $\begin{array}{l}\text { İlgi ve merak uyandırıcı etkinlik } \\
\text { sayısının az olması }\end{array}$ & - & - & - & + & - & - & - & + & - & + & + \\
\hline & Etkinliklerin amaca hizmet etmemesi & - & - & - & + & - & - & - & + & - & + & + \\
\hline & Yönergelerin yeterince açık olmaması & - & - & - & + & - & - & - & - & - & + & + \\
\hline
\end{tabular}

Çalışmaya katılan öğretmenlerin 8'i etkinliklerin yeterli olduğu ifade ederken, 4'ü ise yetersiz bulduklarını açıklamışlardır. Öğretmenler yeterli bulma gerekçelerini; öğrencilerin yaparak yaşayarak öğrenmelerini sağlaması ve 21. yüzyıl becerileri geliştirmesi, öğrencileri araştırmaya sevk etmesi, günlük hayatla ilişkili olması ve bireysel farklılıkları dikkate alması gibi kodlar açıklamışlardır. $\mathrm{K}_{9}$ nolu katılımcı; “Evet etkinlikleri yeterli buluyorum. Öğrenciler çevrelerinde olup biten olayların nasıl gerçekleştiğinin farkında olacaklardır. Ayrıca ögrencilerin yaparak yaşayarak öğrenmelerine ve günlük hayatla konulart ilişkilendirmeye de oldukça katkı sağlayacağını düşünüyorum.” şeklinde görüşünü açıklamıştır. Etkinlikler, konusunda olumlu görüşe sahip olan $\mathrm{K}_{1}$ nolu katılımcı ise; "Etkinlikleri yeterli buluyorum, etkinlikler güzel. Örneğin; astronomi konusunda çocuklardan uzay aracı tasarlanması istenmektedir. Böylece çocuk araştırmaya sevk edilmektedir. Uzay ortamının nasıl bir yer olduğunu hem de orda nasıl bir ortamda bulunacaklarını, nelerle karşılaşacaklarını düşündürmeye sevk ettiği için güzel olmuş." şeklinde görüşünü ifade etmiştir. Ayrıca öğretmenlerden $\mathrm{K}_{7}$; “21.yy ögrencilerin daha çok düşünen, sorgulayan ve araştıran bir nesil olması yönünden bir kitap hazırlandı̆̆ını söyleyebilirim. Etkinlikler genel olarak öğrencileri düşünmeye yeni şeyler üretmeye teşvik etmektedir. Yaşadıkları çevreyi sorgulamaya 
yönlendiriyor. Bu yüzden de uygun buluyorum.” şeklinde görüş bildirmiştir. $\mathrm{K}_{4}, \mathrm{~K}_{8}, \mathrm{~K}_{10}$ ve $\mathrm{K}_{11}$ nolu öğretmenler, ders kitabında yer alan etkinliklerin bazı sınırlılıklarına dikkat çekmişlerdir. $\mathrm{Bu}$ sınırlılıklar sırasıyla; etkinlik sayısının az olması, etkinliklerin ekonomik ve konuyla ilgi yeterli soruların olmaması, ilgi-merak uyandırıcı etkinlik sayısının az olması ve etkinliklerin amaca hizmet etmemesi şeklindedir. $\mathrm{K}_{4}$ nolu öğretmenin bu konudaki görüşü; “Etkinlikler azdır. Ekonomik durumu iyi olmayan yani ek kaynak alamayan çocuklar için yeterli sayıda soru içermiyor. 21.yy becerilerine de uygun bulmuyorum. Çünkü; ilgi çekici merak uyandırıcı etkinlik sayısı az, ders saati uygulama için kısıtlı. Yönergelerinde yeterince açık olmadı̆̆ını ve amaca hizmet etmeyen etkinliklerin de olduğunu düşünüyorum” şeklindedir.

FeTeMM etkinliklerinin Fen Bilimleri ders kitabındaki yeterliliği ve bu etkinliklerin öğrencilerin öğrenmelerine sağlayacak katkılar konusunda Fen Bilimleri öğretmenlerinin görüşleri Tablo 6' da verilmiştir.

Tablo 6. Fen Bilimleri Ögretmenlerinin "FeTeMM etkinliklerinin ders kitabında yeterliliğ ve bu etkinliklerin öğrenmeye sağlayacă̆l katkılar konusundaki düşünceleriniz nedir?" Sorusuna Verdikleri Cevaplardan Oluşturulan Tema ve Kodlar

\begin{tabular}{|c|c|c|c|c|c|c|c|c|c|c|c|c|}
\hline \multirow{4}{*}{ 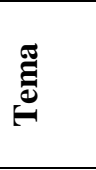 } & \multirow[t]{2}{*}{ Kodlar } & \multicolumn{11}{|c|}{ Fen Bilimleri Öğretmenleri } \\
\hline & & $\mathrm{K}_{1}$ & $\mathrm{~K}_{2}$ & $\mathrm{~K}_{3}$ & $\mathrm{~K}_{4}$ & $\mathrm{~K}_{5}$ & $\mathrm{~K}_{6}$ & $\mathrm{~K}_{7}$ & $\mathrm{~K}_{8}$ & $\mathrm{~K}_{9}$ & $\mathrm{~K}_{10}$ & $\mathrm{~K}_{11}$ \\
\hline & Yeterli buluyorum & - & + & + & - & + & + & + & - & + & - & - \\
\hline & Yetersiz buluyorum & + & - & - & + & - & - & - & + & - & + & + \\
\hline \multirow{9}{*}{ 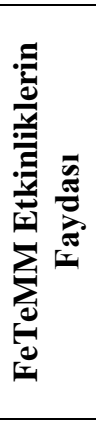 } & $\begin{array}{l}\text { Farklı disiplinleri bir arada kullanılmasını } \\
\text { sağlama }\end{array}$ & + & + & + & - & + & + & + & - & + & - & - \\
\hline & Yaparak yaşayarak öğrenmeyi sağlama & + & + & + & - & + & + & + & - & + & + & - \\
\hline & Problem çözme becerisini geliştirme & + & + & + & - & + & + & + & - & + & - & - \\
\hline & Araştırma sorgulama becerisini geliştirme & + & - & + & - & + & - & + & - & + & - & - \\
\hline & Üretken olmayı sağlama & + & + & + & - & + & + & + & - & + & - & - \\
\hline & Mühendislik beceresini kullanmayı sağlama & + & + & + & - & + & - & + & - & + & - & - \\
\hline & Bilimsel süreç becerisini geliştirme & + & - & + & - & + & - & + & - & + & - & - \\
\hline & 21. yüzyıl becerilerini geliştirme & - & + & + & - & + & + & + & - & - & - & - \\
\hline & Kalıcı öğrenmeyi sağlama & & & & & & & & & & & \\
\hline \multirow{6}{*}{ 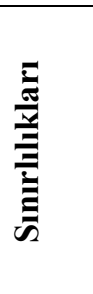 } & $\begin{array}{l}\text { Ögretmenlerin FeTeMM konusunda yeterli } \\
\text { bilgiye sahip olmamaları }\end{array}$ & + & - & + & + & - & + & - & + & - & + & + \\
\hline & Ders saatinin yetersiz olması & + & - & + & + & - & + & - & + & + & + & + \\
\hline & Laboratuvarların donanımlı olmaması & - & + & - & + & + & - & + & + & - & + & + \\
\hline & Sinıfların kalabalık olması & + & + & - & + & + & - & - & + & - & + & + \\
\hline & Araç-gereç eksiğinin olması & + & - & - & + & + & - & - & + & - & + & + \\
\hline & FeTeMM etkinliklerinin teoride kalması & + & - & - & + & - & - & - & + & + & + & + \\
\hline
\end{tabular}

Tablo 6 incelendiğinde; çalışmaya katılan öğretmenlerin 6'sı ders kitabında yer alan FeTeMM etkinliklerini yeterli bulurken, 5 öğretmen yetersiz olduğunu ifade etmişlerdir. 
Öğretmenler FeTeMM etkinlikleri faydalarını; farklı disiplinlerin bir arada kullanılması ve yaparak yaşayarak öğrenmeyi sağlama, problem çözme becerisini geliştirme, mühendislik becerisini ve üretken olmayı sağlama, bilimsel süreç becerisini ve 21 yy becerilerini geliştirme kodları ile dile getirmişlerdir. $\mathrm{K}_{3}$ nolu öğretmen “FeTeMM etkinlikleri daha çok proje şeklinde olduğu için ögrencilerin yaparak yaşayarak ögrenmelerini, onların soyut düşünmeden somut düşünceye geçişini hızlandırır. Bu da bilimsel süreç becerilerini ve yaratıcı düşünmelerini geliştirir." şeklinde açıklama yapmıştır. $\mathrm{K}_{9}$ nolu öğretmen; "FeTeMM etkinliklerinde farklı disiplinlerin bir arada kullanılması amaçlandı̆̆g için öğrencilerin mühendislik tasarım becerilerinin gelişmesine ve üretken olmalarına yardımcı olacaktır. Bu çalışmaların öğrencilerin kendilerini ifade edebilecekleri, araştırarak, sorgulayarak, yaparak yaşayarak kendilerini yetiştirmeleri yönünden iyi sonuçlar doğuracaktır. Üretkenlik artacaktır.” şeklinde beyan etmiştir. Diğer taraftan katılımcılar FeTeMM etkinliklerinin sınırlılıklarını; öğretmenlerin FeTeMM konusunda yeterli bilgiye sahip olmamaları, ders saatinin yetersiz olması, laboratuvarların donanımlı olmaması ve sınıfların kalabalık olması ile açıklamışlardır. $\mathrm{Bu}$ konuda $\mathrm{K}_{4}$ nolu öğretmen; "FeTeMM konusunda öğretmenlerin yeterince bilgilerinin olmadiğını, okullarda araç-gereçlerin eksikliği ve sınıfların çok kalabalık olması nedeniyle bu etkinleri yapmak zor olduğunu düşünüyorum." şeklinde görüş belirtmiştir. FeTeMM etkinlikleri sınırlılığg konusunda $\mathrm{K}_{8}$; “FeTeMM etkinliklerinde tüm çocukları sürece katmak gerekir. Bu da zaman alır fakat; ders saati kısıtlı olduğu için amaca göre yapılmayacaktır. Bu yüzdende tüm çocuklar sürece katılamayacă̆ı için bilimsel süreç becerilerine de bir katkl sağlamayacaktır diye düşünüyorum” şeklinde görüşünü ifade etmiştir. Benzer şekilde $\mathrm{K}_{11}$; "FeTeMM ile araştıran, sorgulayan ve ürün ortaya koyan bireyler yetiştirilir. Fakat; bu uygulamanın somut bir veriye dayanmayacağını, daha önce uygulanan 'performans görevi gibi bir çalışmanın ötesine gidemeyeceğini düşünüyorum, yani teorikte kalacak bilimsel süreç becerisine bir katkısı olmayacaktır diye düşünüyorum" şeklinde görüş bildirmiştir. 
Fen Bilimleri ders kitabının etkili kullanımını artırmak için Fen Bilimleri öğretmenlerinin önerileri Tablo 7’de verilmiştir.

Tablo 7. Fen Bilimleri Öğretmenlerinin "Fen Bilimleri ders kitabının etkili kullanımını arttırmak için önerileriniz nelerdir? Sorusuna Verdikleri Cevaplardan Oluşturulan Tema ve Kodlar

\begin{tabular}{|c|c|c|c|c|c|c|c|c|c|c|c|c|}
\hline Tema & Kodlar & $\mathbf{K}_{1}$ & $\mathbf{K}_{2}$ & $\mathbf{K}_{3}$ & $\mathbf{K}_{4}$ & $\mathbf{K}_{5}$ & $K_{6}$ & $\mathbf{K}_{7}$ & $\mathbf{K}_{8}$ & K9 & $\mathbf{K}_{10}$ & $\mathbf{K}_{11}$ \\
\hline \multirow{5}{*}{ 禀 } & Günlük hayatla ilişkili olmalı & + & + & + & + & + & + & + & + & + & + & + \\
\hline & Öğrenci seviyesine uygun olmalı & + & - & + & + & + & + & + & + & + & + & + \\
\hline & Uygulamaya yönelik olmalı & + & - & + & + & + & + & - & + & - & + & - \\
\hline & $\begin{array}{l}\text { Konular eğitici oyunlarla } \\
\text { desteklenmeli }\end{array}$ & - & + & + & - & + & + & + & + & - & + & - \\
\hline & $\begin{array}{l}\text { Etkinlik yönergelerinin anlaşılır } \\
\text { olması }\end{array}$ & - & + & + & - & + & + & + & + & - & + & - \\
\hline \multirow{5}{*}{ 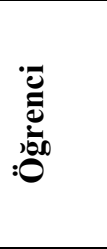 } & Öğrencinin seviyesine uygun olmalı & + & + & + & + & + & + & + & + & + & + & + \\
\hline & $\begin{array}{l}\text { Öğrencilerde öğrenme isteği } \\
\text { uyandırma }\end{array}$ & + & + & + & + & - & + & + & - & + & + & + \\
\hline & Bireysel öğrenmeye elverişli olmalı & + & + & + & + & + & + & + & + & + & - & - \\
\hline & Öğrencileri değerlendirmeli & - & + & - & + & + & - & + & + & - & + & + \\
\hline & Değerlendirme soruları çözülmeli & - & - & + & + & - & + & - & - & + & + & + \\
\hline \multirow{6}{*}{ 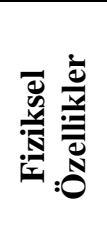 } & Görsel olarak etkili olmalı & + & + & + & + & + & + & + & - & + & + & + \\
\hline & İçerik sade ve anlaşılır olmalı & - & + & + & - & + & + & + & + & + & + & + \\
\hline & Ekonomik olmalı & - & + & + & - & + & + & - & + & + & + & + \\
\hline & Kaliteli kağıttan yapılmalı & + & + & - & + & - & + & + & - & - & + & + \\
\hline & Hafif taşınabilir olmalı & + & - & + & - & + & - & - & + & + & + & - \\
\hline & Kitaptaki soru sayısı artırılmalı & - & + & + & + & - & - & + & + & - & - & - \\
\hline
\end{tabular}

Tablo 7 incelendiğinde, öğretmenlerin etkili ders kitabı konusundaki görüşleri, “Etkinlik”, “Öğrenci” ve "Fiziksel Özellikler” teması altında toplandığı görülmektedir. Öğretmenler, etkinliklerin günlük hayatla ilişkili, öğrenci seviyesine uygun, uygulamaya yönelik ve yönergelerinin açık olmasını ifade etmişlerdir. Etkinlikler teması altında görüş beyan eden $\mathrm{K}_{6}$ nolu öğretmen; "Etkinliklerin yönergeleri daha açık ve anlaşılır olmalı. Etkinliklerin konulara göre seçimi daha uygun yapılmall. Etkinlikler günlük hayatla ilişkilendirilerek uygulanabilirliği ve kalıcılı̆̆ı artırılmalıdır. " şeklinde görüşünü açıklamıştır. Bunun yanı sıra öğretmenler ders kitaplarının, öğrenci seviyesine uygun olmasını, öğrencileri değerlendirmesi, öğrencelerde öğrenme isteği uyandırması ve bireysel öğrenmeyi sağlamasını dile getirmişlerdir. $\mathrm{K}_{8}$ nolu öğretmen, "Ders kitaplarl, öğrencilerin bilişsel seviyelerine uygun olması, ögrrencilerin konuyu öğrenip öğrenemediğini ortaya çıkarmalıdır. Çünkü her sınıfta farklı bireysel özelliklere sahip öğrenciler bulunmaktadır. Kitaptaki bilgiler bu doğrultuda 
hazırlanması gerekmektedir." şeklinde görüş bildirmiştir. Ayrıca öğretmenler ders kitabının fiziksel özelikleri ile ilgili olarak; ekonomik, görsel olması, içeriğin sade ve anlaşılır olması, kaliteli kağıttan yapılmalı ve taşınabilir olması gerektiğini vurgulamışlardır. $\mathrm{K}_{10}$ nolu öğretmen; "Ders kitaplarının ekonomik olmasına ve kullanılan görsellerin renkli ilgi çekici ve içeriği yansıtması gerekmektedir. Bunun yanı sıra konu sonundaki değerlendirme sorularının önemini anlatarak çözmelerini teşvik etmeliyiz ve yeni eklenen çıkmış soruların hepsini de çözmeliyiz. Böylece çocuklar ders kitabını daha çok önemser diye düşünüyorum.” şeklinde ifade etmişlerdir.

\section{Tartışma ve Sonuç}

Fen Bilimleri öğretmenleri öğretim programındaki yapılan değişiklikleri; üniteler arasında yer değişikliğinin yapılması, FeTeMM eğitimine yer verilmesi, konularda sadeleştirmelerin yapılması, uygulanabilir etkinliklere daha çok yer verilmesi ve kazanım sayısının azaltılması şeklinde açıklamışlardır. Öğretim programında meydana gelen bu değişim, öğretmenler üzerinde olumlu etki oluşturduğu söylenebilir. Çünkü öğretim programında yapılan bu değişiklik, çağın gereksinimleri, öğretmenlerin öğretme anlayışları, öğrencilerin hazır bulunuşlukları ve bireysel farklılıkları dikkate alınarak gerçekleştiği düşünülmektedir. Ayrıca öğretim programına FeTeMM eğitiminin eklenmesi, ders kitaplarında bu etkinlerin yer almasını ortaya koymuştur. Bu durum, öğretmenlerin birçok disiplinin Fen Bilimleri dersinde yer aldığının farkında olmalarını sağlamıştır. Böylece öğrencilerin meslek seçiminde bu disiplinlere yönelimlerine öğretmenlerin rehberlik etmeleri ortaya çıkmıştır. FeTeMM eğitiminin, öğretim programlarında yer alması gerekli kılan şartlardan birisi de öğrencilerin fenteknoloji-matematik ve mühendislik alanlarına tercih eden öğrenci sayısını artırmaktır (Akgündüz, Aydeniz, Çakmakçı, Çavaş, Çorlu, Öner ve Özdemir, 2015). Bu açıdan bakıldığında öğretim programında yapılan bu değişikliğin, öğretmenler açısından olumlu bir değişiklik olduğu görülmektedir. Bakırcı ve Kutlu (2018), Fen Bilimleri öğretmenleri FeTeMM 
eğitiminin öğretim programında yer almasını olumlu olduğunu belirtmişlerdir. Buna karşın öğretmenler, FeTeMM etkinliklerinin birtakım sınırlılıklarının olduğunu dile getirmişlerdir. Bu sınırlılıkların, FeTeMM eğitiminde öğretmenlerin hizmet içi eğitime ihtiyaçlarının olması, sınıfların kalabalık olması ve okullarda yeterince araç-gerecin olmaması şeklindedir.

Öğretmenlerin, beşinci sınıf Fen Bilimleri ders kitabının genel taslağı hakkında görüşleri görsellik ve içerik teması altında toplanmıştır. Öğretmenler; kitabın, parlak, renkli, canlı, kaliteli kağıt kullanılarak yapıldığını ve merak uyandırıcı bir görsele sahip olduğunu ifade etmişlerdir. Bu durumun ise öğretmenlerin ders anlatımlarını kolaylaştıracağı, öğrencilerin derse odaklanmalarını sağlayacağı ve motivasyonlarını artıracağı söylenebilir. Ders kitabının görselliği konusunda öğretmenlerin olumlu görüşe sahip olmaları, öğrencilerin fen konularını öğrenmelerinde önemli rol oynayacağını ortaya koymaktadır. Aybek, Çetin ve Başarır (2014), Fen Bilimleri ders kitabını öğretmen görüşü doğrultusunda incelemiş olduğu çalışmada, öğretmenlerin ders kitabının görsel ve içerik olarak iyi tasarlandığını belirtmişlerdir. Bu durumun öğrenmeyi kolaylaştıracağını dile getirmişlerdir. Bu çalışmada öğretmenlerin beşinci sınıf Fen Bilimleri ders kitabı hakkında görüşleri alan yazın yapılan çalışmaların sonuçları benzerlik gösterdiği söylenebilir. Öğretmenler ders kitabının içeriğini; konular, etkinlikler, ölçme ve değerlendirme ve sınırlılıklar bağlamında açıklamışlardır. Öğretmenler, konuların sadeleştirildiği, güncel örneklere daha çok yer verildiğini belirtmişlerdir. Bunun yanında etkinliklerin öğrencilerin seviyelerine uygun, etkileyici, merak uyandırıcı olduğunu söylemişlerdir. Ölçme değerlendirme bölümünde yer alan soruların, merkezi sınavda çıkmış veya çıkabilecek sorulardan oluştuğu, farklı düzeydeki öğrencilere uygun olduğunu, öğrencilerin konuyu öğrenip öğrenmediğini ortaya çıkardığı ve üst düzey bilişsel düzeylerini ortaya çıkardığını dile getirmişlerdir. Öğretmenlerden ikisi ders kitabında yer alan değerlendirme soruların yetersiz olduğunu söylemişlerdir. Bu durum, öğrencilerin konuyu öğrenip öğrenmedikleri tam olarak ortaya çıkaramayacaktır. Bundan dolayı öğretmenler 
değerlendirme sorularının yetersizliğini ders kitabın bir sınırlılı̆̆ı olarak gördüklerini belirtmişlerdir.

Fen Bilimleri öğretmenleri; bilim kahramanlarının, yaratıcı etkinliklerinin, güncel örneklerin ve göster kendini etkinliklerinin ders kitabında yer almasını, kitabında görülen yenilik olarak ifade etmişlerdir. Çalışmaya katılan öğretmenlerin büyük çoğunluğu ders kitabına bilimin kahramanları bölümünün eklenmesi, öğrencilerde merak oluşturarak, onların fen bilimleri ile ilgili mesleklere yönelimlerinin artacağını ifade etmişlerdir. Ayrıca bu bölümün eklenmesi öğrencilerde bilim insanı olmanın imkansız olmadığını, öğrenciler isterlerse bilim insanı olacağını dile getirmişlerdir. Öğretmenler, göster kendini etkinlikleri ile öğrencilerin yaratıcılıklarının artacağını, pekiştirici etkinliklerle aktif öğrenme yapacaklarını, verilen güncel örneklerle öğreneceklerini günlük hayatta kullanabileceklerini böylece sıkılmadan öğrenmeye istekli bir şekilde dersi dinleyeceklerini belirtmişlerdir. Öğretmenlerin ders kitabı hakkında olumlu düşüncelerinde, mesleki deneyimleri, bundan önceki ders kitaplarının içeriğine hakim olmaları, meslektaşları ile görüş alışverişleri ve öğrenci gözlemleri etkili olduğu söylenebilir. Öğretmenler, ders kitabında meydana güncellemelerin öğrenmeye yansımalarının olacağını belirtmişlerdir. $\mathrm{Bu}$ yansımaların, öğrencilerde kalıcı öğrenmenin sağlanması, öğrencilerin yeteneklerinin farkında olmaları, öğrenmenin kolaylaşacağı, bilim insanı olmayı özendirmesi ve 21. yy becerilerini kazandırılması şeklinde sıralanmaktadır. Öğretmenlerde bu olumlu düşüncelerin oluşmasında, ders kitabına gelen yeniliklerin zengin içeriğe sahip olması, günlük hayatla ilişkili olması ve öğrencilerin yeteneklerin ortaya çıkmasına hizmet etmesi ve bireysel farklılıkların dikkate alması gibi değişkenler etkili olmuş olabilir.

Çalışmaya katılan Fen Bilimleri öğretmenlerinin bir kısmı (yedi öğretmen) ders kitabındaki etkinlikleri yeterli bulurken, bazıları (dört öğretmen) ise yeterli bulmadığını ifade etmiştir. Öğretmenlerin, ders kitabındaki etkinlikler ilgili düşünceleri etkinliklerin faydası ve sınırlılıkları teması altında toplanmıştır. Öğretmenlere göre etkinlikler, yaparak yaşayarak 
öğrenmeyi, araştırma yapmayı, 21. yy becerileri geliştirmeyi, günlük hayatta ilişkili olmayı ve bireysel farklılıkları dikkate almayı ve düşünmeyi sağlamaktadır. Öğretmenlerin bu görüşlerinde, ders kitaplarının öğretim programının amaçları doğrultusunda hazırlanmış olması ile açıklanabilir (MEB, 2018). Bunun yanı sıra ders kitaplarının nitelikli insan yetiştirmede önemli bir yere sahip olması ile de ilişkilendirilebilir. Öğretmenler ile yapılan görüşmede, etkinliklerin öğrencilerde yaparak yaşayarak öğrenmeyi artırdığı, onları yeni şeyler üretmeye teşvik ettiği yani isteseler küçük mucitler olabileceklerini ifade etmişlerdir. Öğrencileri araştırma-sorgulamaya sevk ederek 21. yüzyı becerilerinin oluşmasını sağlayacağını belirtmişlerdir. Kitaptaki etkinlikler öğrencileri çevrelerini sorgulamayı ve yaşadıkları çevrede olup bitenleri tanımayı teşvik etmektedir. Başka bir ifadeyle meraklı bireylerin yetişmesini sağlayarak, onların 21.yy becerilerini ve yaratıcı düşünmelerini gelişimine katkı sağladığı söylenebilir. Bakırcı ve Öçsoy’un (2017), Fen Bilimleri ders kitabında yer alan etkinlikleri girişimcilik bağlamında inceledikleri çalışmada, çalışmaya katılan Fen Bilimleri öğretmenlerinin yarısından fazlası etkinliklerin öğrencilerin girişimcilik becerisini geliştirme yeterliliğine sahip olduğunu ifade ederken, diğer kısmı ise yetersiz olduğunu ifade etmişlerdir. Öğretmenlerin beşinci sınıf ders kitabında yer alan etkinliklerle ile ilgili görüşlerinin, daha önce yapılan çalışmaların sonuçları benzerlik gösterdiği anlaşılmaktadır. Diğer taraftan öğretmenler etkinliklerin sınırlılıklarını; etkinlik sayısının az olması, ekonomik ve yeterli değerlendirme sorularını, yönergelerin açık olmaması, ilgi ve merak uyandırıcı etkinliklerin az olduğunu şeklinde açıklamışlardır. Yıldız-Feyzioğlu ve Tatar (2012), etkinliklerde öğrencilerin aynı öğretimsel iş üzerinde çalışma oranı yüksektir ve bu nedenle kitaplar grup çalışmasına dayalı öğrenme ortamlarını oluşturmak açısından sınırlı olduğunu belirtmişlerdir.

Çalışmaya katılan öğretmenlerin yarısı Fen Bilimleri ders kitabındaki FeTeMM etkinliklerini yeterli görürken, diğer yarısı ise yeterli görmediklerini belirmişlerdir (Tablo 6). Ders kitabında yer alan FeTeMM etkinliklerinin yeterli olduğunu düşünen öğretmelerin 
görüşlerinde birçok değişkenin etkili olduğu düşünülmektedir. Bunlardan birincisi, öğretmenlerin çalıştığı okulun merkezi bir okul olması, teknolojik açıdan donanımlı olması, sınıf mevcudunun kalabalık olmaması ve araç-gereç açısından ideal bir fen laboratuvarına sahip olmasıdır. İkincisi ise FeTeMM'de iki disiplinin yer almış olmasıdır (örneğin fen ve matematik). Alan yazın incelendiğinde bu konuda öğretmenlerin görüşünü destekleyen çalışmaların olduğu söylenebilir. Örneğin, Smith ve Karr-Kidwell (2000), FeTeMM eğitimini, en az iki FeTeMM disiplininin (fen, teknoloji, mühendislik ve matematik) entegre edilerek işlenen konu ve gerçek hayat arasında bağlantılar kuran bir sınıf, ünite ya da dersi birleştirme biçimi olarak tanımlamışlardır. $\mathrm{Bu}$ tanımda FeTeMM eğitiminin olması için, iki disiplin olmasının yeterli olduğu anlamı çıkarılabilir. Bu açıdan bakıldığında öğretmenlerin FeTeMM eğitimi hakkında yeterli bilgiye sahip olduklarını gösterdiği söylenebilir.

Diğer taraftan beş öğretmen FeTeMM etkinliklerinin ders kitabında yetersiz olduğunu ifade etmişlerdir. Öğretmenlerin bu görüşlerinde; onların FeTeMM konusunda yeterli bilgiye sahip olmaları ya da bu konuda yetersiz olmaları ile açıklanabilir. Öğretmenlerin bu şekilde düşünmelerinin başka bir sebebi olarak, öğretmenlerin FeTeMM etkinliklerinde dört farklı disiplinin (fen-teknoloji-matematik-mühendislik) bir etkinlikte olması gerektiği anlayışına sahip olmaları gösterilebilir. Öğretmenlerin bu şekilde görüş beyan etmelerinde; ilgili etkinliklerde, bu dört disiplini görmemiş olmalarının etkili olduğu düşünülmektedir. Bu konuda Moore, Stohlmann, Wang, Tank ve Roehrig (2014) yapmış oldukları çalışmalarında, FeTeMM eğitimini; fen, teknoloji, mühendislik ve matematiği dört ayrı alan olarak kabul edip, bu alanların birbirinden bağımsız şekilde öğretilmesi olarak açıklamışlardır. $\mathrm{Bu}$ tanımda anlaşılacağı üzere FeTeMM eğitimine göre tasarlanan etkinlikte dört disiplinin kullanılması gerektiği anlaşılmaktadır. Yapılan bir başka çalışmada, Fen Bilimleri öğretmenleri, FeTeMM eğitimi için uygun öğrenme ortamının olmadığını belirtmişlerdir. Öğretmenler, sınıfların 
kalabalık olduğuna, yeterli araç gerecin olmadığına ve öğretmenlerin FeTeMM konusunda yeterli bilgiye sahip olmadıklarına dikkat çekmişlerdir (Bakırcı ve Kutlu, 2018).

Fen Bilimleri öğretmenleri, ders kitabında yer alan FeTeMM etkinliklerinin yararlarını, öğrencilerin farklı disiplinleri bir arada kullanmalarını ve yaparak yaşayarak öğrenmelerini sağladığını, araştırma sorgulama becerilerini ve bilimsel süreç becerilerini geliştirdiğini ifade etmişlerdir. Bunun yanı sıra öğrencilerin mühendislik becerilerini kullanmayı ve kalıcı öğrenmeyi sağladığını dile getirmişlerdir. Bu bulgu, öğretmenlerin FeTeMM etkinlikler ile ilgili teorik bilgiye sahip olduklarını ortaya koymaktadır. 2017 yılından itibaren Fen Bilimleri Dersi Öğretim Programı'nda FeTeMM eğitiminin yer alması öğretmenlerin bu konuda araştırmalar yapmış olmaları ve bu konuda hizmet içi eğitim kurslarına katılmış olmaları bu konuda bilgi edinmelerini sağlamış olabilir. Nitekim alan yazın incelendiğinde, öğretmenlerin bu görüşlerini destekleyen birçok çalışmanın olduğu söylenebilir (Bakırcı ve Karışan, 2018; Denson, 2011; Tarkın-Çelikkıran ve Aydın-Günbatar, 2017; Thomas, 2014).

Öğretmenler, FeTeMM etkinliklerinin birtakım sınırlılıklarının olacağını ifade etmişlerdir. Bu sınırlılıklar; öğretmenlerin FeTeMM konusunda yeterli bilgiye sahip olmamaları, laboratuvarlarda yeterli araç gerecin olmaması, ders saatinin yetersiz ve sınıfların kalabalık olması şeklindedir. Öğretmenlerin FeTeMM hakkında yeterli bilgiye sahip olmamaları, FeTeMM eğitiminin öğretim programında 2017 yılından itibaren yer alan yeni bir eğitim yaklaşımı olması ve öğretmenlerin üniversite yıllarında bu konuda herhangi bir ders almamaları ile açıklanabilir. Güncellenen öğretim programının pilot uygulamadaki eksikliği ve öğrenme ortamı ile öğretim programlar arasındaki boşluk ile açıklanabilir. Bu çalışmada, FeTeMM etkinlikleri ile ilgili öğretmenlerin ifade ettikleri sınırlılıklara birçok çalışmada rastlamak mümkündür (Bakırcı ve Kutlu, 2018; Ceylan, 2014; Eroğlu ve Bektaş, 2016).

Fen Bilimleri öğretmenleri ders kitaplarının etkili kullanımı artırmak için, etkinliklerin günlük hayatla ilişkili, öğrenci seviyesine uygun ve uygulamaya yönelik olması, oyunlarla 
desteklenmesi gerektiğini belirtmişlerdir. Bunun yanında etkinliklerin öğrencilerde öğrenme isteği uyandırmayı, bireysel öğrenmeyi ve öğrencileri değerlendirmeyi sağlaması gerektiğini ifade etmişlerdir. Ayrıca öğretmenler, kitapların görsel ve ekonomik olduğunu, kaliteli kağıttan yapıldığını, hafif, taşınabilir olduğunu ve içeriğinin sade-anlaşılır olduğunu vurgulamışlardır (Tablo 7). Bu bulgu, öğretmenlerin bir kitapta bulunması gereken özelliklerin neler olması gerektiğini bildiklerini ortaya koymaktadır. Öğretmenlerin bu şekilde görüş ortaya koymalarında, onların üniversite öğretim kademesinde konu alanı ders kitabı dersini almış olmalarından kaynaklanmış olduğu düşünülmektedir. Alan yazında kitap incelemesi ilgili çalışmalar elde edilen sonuçların, bu çalışmadaki öğretmen görüşleri doğrultusunda olduğu görülmüştür (Bakırcı ve Öçsoy, 2017; Karamustafaoğlu, Salar ve Celep, 2015).

\section{Öneriler}

Öğretmenler, etkinlikler için ders saatinin ve öğrencilerin değerlendirildiği soruların arttırılmasını, kitaptaki tüm etkinliklerin yapılmasını ve günümüz sınav sistemlerinin daha çok öğrencilerin bilimsel süreç becerilerini odaklandığı için ders kitaplarında bu tür etkinliklerin artırılmasını önermişlerdir.

Ders kitabındaki ölçme değerlendirme sorularının, Liselere geçiş Sınavı (LGS)’nda çıkan sorular bağlamında incelenmesine yönelik çalışmaların yapılarak, kitaptaki soruların bu sınavda çıkan sorular ile örtüşme durumu ortaya çıkarılması gerekmektedir.

Ders kitabındaki FeTeMM etkinlik sayısını artırılarak, öğrencilerin üst düzey düşünme becerilerini geliştirme sağlanmalıdır.

Haftalık Fen Bilimleri ders saati artırılarak, öğretmenlerin ders kitabında yer alan tüm etkinlikleri işlemesine olanak verilmelidir. 


\section{Makalenin Bilimdeki Konumu}

Matematik ve Fen Bilimleri Eğitimi Bölümü/ Fen Bilgisi Eğitimi

\section{Makalenin Bilimdeki Özgünlüğü}

Alan yazında ders kitaplarının incelenmesini konu alan çalışmalarda farklı bakış açılarının temel alındığı çalışmalara rastlanmaktadır. Ancak Fen Bilimleri ders kitaplarının bir bütün halinde ve öğretim programına uygunluğu ile ilgili yeterli çalışmanın yer almadığı tespit edilmiştir. Bu nedenle ortaokul beşinci sınıf Fen Bilimleri ders kitabı programa uygunluk, bilimsel içerik, görsel düzen, güncel olma, ölçme değerlendirme boyutlarında incelemeye alınmıştır.

\section{Kaynaklar}

Akgündüz, D., Aydeniz, M., Çakmakçı, G., Çavaş, B., Çorlu, M. S., Öner, T. ve Özdemir, S. (2015). STEM eğitimi Türkiye raporu: Günün modası mi yoksa gereksinimi? İstanbul: Aydin Üniversitesi.

Aybek, B., Çetin, A., ve Başarır, F. (2014). Fen ve teknoloji ders kitabının eleştirel düşünme standartları doğrultusunda analiz edilmesi. Eğitim ve Öğretim Araştırmaları Dergisi, 3(1), 313-325.

Aydoğdu, M. ve Kesercioğlu, T. (2005). İlköğretimde fen ve teknoloji öğretimi. Ankara: An1 Yayınc1l1k.

Bakırcı, H. ve Karışan, D. (2018). Investigating the preservice primary school, mathematics and science teachers' stem awareness. Journal of Education and Training Studies, 6(1), $32-42$.

Bakırcı, H. ve Kutlu, E. (2018). Fen bilimleri öğretmenlerinin FeTeMM yaklaşımı hakkındaki görüşlerinin belirlenmesi. Türk Bilgisayar ve Matematik Eğitimi Dergisi, 9(2), 367-389. 
YYÜ Ĕ̌itim Fakültesi Dergisi (YYU Journal of Education Faculty), 2018; 15(1):638-671, http://efdergi.yyu.edu.tr

Bakırcı, H. ve Öçsoy, K. (2017). Fen bilimleri ders kitaplarında yer alan etkinliklerin girişimcilik bağlamından incelenmesi. Adıyaman Üniversitesi Eğitim Bilimleri Dergisi, 7(2), 256-276.

Ceylan, S. (2014). Ortaokul fen bilimleri dersindeki asitler ve bazlar konusunda fen, teknoloji, mühendislik ve matematik (FeTeMM) yaklaşımı ile öğretim tasarımı hazırlanmasına yönelik bir çalışma. Yüksek lisans tezi, Eğitim Bilimleri Enstitüsü Uludağ Üniversitesi, Bursa.

Çepni, S. (2007). Araştırma ve proje çalışmalarına giriş. Trabzon: Celepler Matbaacılık.

Denson, C. (2011). Building a framework for engineering design experiences in STEM: A synthesis. National Center for Engineering and Technology Education. 169, 1-6.

Drake, C., L. \& T. J., Tyminski, A. M. (2014). Öğretmen adaylarının bilgi geliştirme desteği için eğitim müfredatı malzemelerinin kullanımı. Amerikan Ĕ̆gitim Araştırmaları Derneği, 43(3), 154-162.

Eroğlu, S. ve Bektaş, O. (2016). STEM eğitimi almış fen bilimleri öğretmenlerinin STEM temelli ders etkinlikleri hakkındaki görüşleri. Eğitimde Nitel Araştırmalar Dergisi $4(3), 43-67$.

Denson, C. (2011). Building a framework for engineering design experiences in STEM: A synthesis. National Center for Engineering and Technology Education. 169, 1-6.

Kaptan, F. (1999). Fen bilgisi öğretimi (3. baskı). İstanbul: Millî Eğitim Basımevi.

Karadaş, A., Yaşar, I. Z. ve Kırbaşlar, F. G. (Haziran, 2012). 6-8. sınıf fen ve teknoloji kitaplarındaki madde ve değişim öğrenme alanında yer alan etkinliklerin incelenmesi. $X$. Ulusal Fen Bilimleri ve Matematik Eğitimi Kongresi. Niğde Üniversitesi Eğitim Fakültesi, 27-30 Haziran, Niğde.

Karamustafaoğlu S., Salar, U., Celep, A. (2015). Ortaokul 5. sınıf fen bilimleri ders kitabına yönelik öğretmen görüşleri. Gazi Eğitim Bilimleri Dergisi, 2(1), 93-118. 
Kardaş, N., Anagün, Ş. S. ve Yalçınoğlu, P. (2014). Problem çözme envanterini ilköğretim öğrencilerine uyarlama çalışması: Doğrulayıcı faktör analizi sonuçları. Elektronik Sosyal Bilimler Dergisi, 13(51), 182-194.

Keleş, E. (2001). Fizik ders kitaplarını değerlendirme ölçeği. Yayımlanmamış yüksek lisans tezi, Fen bilimleri Enstitüsü, Karadeniz Teknik Üniversitesi, Trabzon.

Kılıç, D. (2005). Konu alanı ders kitabı incelemesi. (Ed. Ö. Demirel ve K. Kıroğlu). Ders kitabının ögretimdeki yeri içinde (s.37-53). Ankara: Pegema Akademi Yayıncılık.

Kolaç, E. (2009). İlköğretim Türkçe ders kitaplarında yer alan metinlerin tür açısından değerlendirmesi. Uluslararası İnsan Bilimleri Dergisi, 6(1), 105-137.

Kurnaz, M. A., Çevik, E. E. ve Bayri, N. G. (2016). Fen ve teknoloji ders kitaplarındaki gösterim türleri arası geçişlerin incelenmesi. Cumhuriyet International Journal of Education, 5(3), $3-47$.

Maskan, A. K., Maskan, M. H. ve Atabey, K. (2007). İlköğretim 4. sınıf fen ve teknoloji ders kitabının değerlendirme ölçütleri yönünden incelenmesi. Dicle Üniversitesi Ziya Gökalp Eğitim Fakültesi Dergisi, 9, 22-32.

Milli Ĕ̆itim Bakanlı̆̆ı (2018). Fen bilimleri dersi öğretim programı (ilkokul ve ortaokul 3, 4, 5, 6, 7 ve 8. sinıflar) ögretim programı. Ankara: Devlet Kitapları Basım Evi.

Millî Eğitim Bakanlığı. (2013). İlköğretim kurumlarl fen bilimler dersi (3, 4, 5, 6, 7 ve 8. sinıflar) öğretim programı. Ankara: Devlet Kitapları Basım Evi.

Millî Eğitim Bakanlığı. (1995). Ders kitapları yönetmeliği. Ankara: Pegema Akademi Yayınc1l1k.

Miles, B. M., \& Huberman A. M. (1994). Qualitative data analysis: An expanded source book. California, USA: Sage Publications.

Moore, T. J., Stohlmann, M. S., Wang, H.-H., Tank, K. M., \& Roehrig, G. H. (2014). Implementation and integration of engineering in K-12 STEM education. In J. Strobel, 
S., Purzer, \& M. Cardella (Eds.), Engineering in precollege settings: Research into practice. West Lafayette, IN: Purdue Press.

Özcan, H. ve Düzgünoğlu, H. (2017). Fen bilimleri dersi 2017 taslak öğretim programına ilişkin öğretmen görüşleri. International Journal of Active Learning, 2(2), 28-47.

Patton, M. Q. (2014). Nitel araştırma ve değerlendirme yöntemleri (3. Baskıdan Çeviri) (M. Bütün ve S. B. Demir). Ankara: Pegema Akademi.

Smith, J., \& Karr-Kidwell, P. J. (2000). The Interdisciplinary Curriculum: A Literary Review and a Manual for Administrators and Teachers. http://files.eric.ed.gov/fulltext/ED443172.pdf adresinde 08.07.2018 tarihinde alınmıştır.

Taber, K. S. ve Akpan, B. (Eds.). (2017). Secince education: An international course companion. Springer.

Tarkın-Çelikkıran, A. ve Aydın-Günbatar, S. (2017). Kimya öğretmen adaylarının FeTeMM uygulamaları hakkındaki görüşlerinin incelenmesi. Yüzüncü Yıl Üniversitesi Ĕ̆itim Fakültesi Dergisi, 14(1), 1624-1656.

Thomas, T. A. (2014). Elementary teachers' receptivity to integrated science, technology, engineering, and mathematics (STEM) education in the elementary grades (Doctoral dissertation, University of Nevada, Reno). Retrived from https://scholarworks.unr.edu/handle/11714/2852

Tor, H. ve Erden, O. (2004). İlköğretim öğrencilerinin bilgi teknolojilerinden yararlanma düzeyleri üzerine bir araştırma. The Turkish Online Journal of Educational Technology, $3(1), 120-130$.

URL-1, $2017 \quad$ https://fatihegitim.files.wordpress.com/2011/03/hafta-45c3b6c49fretimprogramlarc4b1na-uygunluk.ppt

Ünsal, Y. ve Güneş, B. (2003). İlköğretim altıncı sınıf fen bilgisi ders kitabının fizik konuları yönünden incelenmesi. Gazi Üniversitesi, Gazi Ĕ̆itim Fakültesi Dergisi, 23(3), 115-130. 
YYÜ Eğitim Fakültesi Dergisi (YYU Journal of Education Faculty), 2018; 15(1):638-671, http://efdergi.yyu.edu.tr

Yıldırım, A. ve Şimşek, H. (2011). Sosyal bilimlerde nitel araştırma yöntemleri. Ankara: Seçkin Yayınları.

Yıldırım, Ü. N., Ateş, S. (2002). İlköğretim yedinci sınıf fen bilgisi ders kitabının fen bilgisi öğretmenlerine göre yeterlilik derecesinin araştırılması. Abant izzet Baysal Üniversitesi Ĕ̌itim Fakültesi Dergisi, 3(5), 78-86.

Yıldız-Feyzioğlu, E. ve Tatar, N. (2012). Fen ve teknoloji ders kitaplarındaki etkinlikleri bilimsel süreç becerilerine ve yapısal özelliklerine göre incelenmesi. Eğitim ve Bilim, 37, 164. 


\section{Statement of Problem}

\section{Summary}

Changes in curricula are crucial in order for learners to achieve pre-determined learning goals and adapt to the changing world (Drake, Land and Tyminski, 2014, Taber and Akpan, 2017, p. 23). There has been several changes in education programs in Turkey at different times. The textbooks are prepared on the basis of teaching programs. The textbooks in education are prepared according to the teaching and learning principles indicated by the curriculum. In 2017, the curriculum of the Science Teaching Course was updated, and it was decided to apply it gradually from the fifth year of secondary school. The changes in the program necessitated the need to change the textbooks. One of the textbooks that have been revised has been the book of the 5th grade science textbook of secondary school.

Revised science textbooks started to be used in the 5th grade from 2017-2018 academic year onwards. It is believed that the opinions of teachers who use the textbooks in their lessons are important. There is also no research on this topic in the literature. Based on the literature presented above, it was found out that studies on textbooks are based on different perspectives, but that there are not adequate research looking at the appropriateness of textbooks to the curriculum. For this reason, teachers' views were taken to understand program suitability, scientific content, visual arrangements and revisions of the textbook.

\section{Method}

This research is a qualitative study investigating teachers' views on the 5th grade science textbook revised in 2017. The study employs phenomenology design. This research was carried out with 11 science teachers (8 female and 3 male teachers) working in different secondary schools in Van during 2017-2018 academic years. Semi-structured interviews were used. Descriptive and content analysis was utilized for data analysis. 


\section{Findings}

When Table 2 is examined, teachers described the changes made in the curriculum as change of the chapters, introduction of STEM education, interesting topics and feasible activities. Nine of the teachers stated that units (chapters) were changed in the curriculum.

When Table 4 is examined, the teachers described the innovations in the book as introduction of science heroes, creative activities, recent examples, and reinforcing activities. Almost all teachers stated that science heroes and creative activities in textbooks are quite innovative. Teachers have indicated that the revisions in the textbook will facilitate learning, provide permanent learning and help students discover their abilities, encourage them to be a scientist, promote creative thinking, and increase academic success. Four teachers have indicated the textbook provides examples from everyday life, and that these examples will help students understand how science is intertwined with daily life.

Eight teachers stated that the activities were sufficient, whereas 4 teachers found them insufficient (Table 5). Teacher who found the activities sufficient provided following codes of justifications: encouraging students learn by living, developing 21 st century skills, encouraging students to research, drawing connections with daily life and taking individual differences into account. Four teachers pointed out some limitations of the activities in the course book. These limitations are as follows; the number of activities is limited, the activities are not economical and they do not address the related problems of the topic, the number of interesting activities is limited, and the activities do not fit the purpose.

\section{Discussion and Conclusion}

Science teachers explained that the changes made in the teaching curriculum as changing the order of chapters, the inclusion of STEM education, simplifications in the contexts, feasible activities, and reduction in the number of learning outcomes. This change in the curriculum can be interpreted as a positive effect on students' learning. This is because the 
change in the curriculum is thought to take into account the needs of the age, readiness of the students and individual differences. In addition, introducing STEM education to the curriculum has revealed that these activities are included in textbooks. This will ensure that students are aware that many disciplines are involved in Science. In this way, students will be more likely to opt for these disciplines and science related professions. One of the reasons for STEM education to be included in teaching programs is to increase the number of students who prefer science, technology, mathematics and engineering fields (Akgündüz, Aydeniz, Çakmakçı, Çavaş, Çorlu, Öner and Özdemir, 2015). From this point of view, this change in the curriculum seems to be a positive change in terms of teachers. Bakırc1 and Kutlu (2018) also found in their research that science teachers were happy with introduction of STEM education in education programmes. On the other hand, they have found that teachers have in-service training needs in the implementation of STEM activities, the classes are crowded and that there is not enough tools in school (Bakırcı and Kutlu, 2018).

Science teachers have expressed that the novelty of textbook are science heroes, creative activities, current examples and show activities. Most of the teachers indicated that the section of the heroes of science will raise students' interest in science-related professions by creating curiosity among the students. The addition of this section will also show students that it is not impossible to be a scientist, and that they would become scientists if they want to. Teachers indicate that show yourself activities of the students will increase with their creativity, activities will enable them to be active learners and recent examples provided in the book will teach them how to use what they have learned in daily life. Overall, teachers believe students feel more enthusiastic about learning. It is believed that teachers have a positive attitude towards their textbooks, and their professional experiences, their knowledge on the content of previous textbooks, exchange of views with their colleagues and student observations may have played a role in constructing the positive attitudes. Teachers have indicated that innovations in the 
textbook will be reflected in learning. Teachers have indicated that revisions in the textbook will be reflected in learning. These reflections include providing permanent learning, making students be aware of their skills, facilitating learning, encouraging them to become scientists, and gaining $21^{\text {st }}$ century skills. In the formation of these positive thoughts in the teachers, variables such as rich content in textbooks, authentic materials in the textbook, and helping students to show their talents and considering individual differences may have been effective. 